\title{
Convergent and Parallel Evolutionary Traits in Early Cretaceous Rudist Bivalves (Hippuritidina)
}

\section{Masse JP* and Fenerci Masse M}

Aix-Marseille University, France

*Corresponding author: Jean Pierre Masse, Aix-Marseille University, Place Victor Hugo. 13331 Marseille Cedex 03, France, Email: jean-pierre.masse@hotmail.com

\section{Review Article}

Volume 4 Issue 1

Received Date: December 07, 2020

Published Date: January 12, 2021

\section{Abstract}

Early Cretaceous Hippuritida clades, requieniide (family Requieniidae) and hippuritide (families Radiolitidae, Polyconitidae, Caprinidae, "Caprinulidae" and Caprinuloideidae), show distinctive myophoral arrangements and shell structures. Nevertheless they share some characters, such as the transverse shell thickening of the myophores of the attached valve which are convergent traits in Lovetchenia (Requieniidae) and Homopleura (Monopleuridae). The bent posterior myophore of the right valve of Pseudotoucasia (Requieniidae) closely resemble the posterior myophore of the left valve of Horiopleura and Polyconites (Polyconitidae). The shell cellular structure is one of the key attributes of the family Radiolitidae (e.g. Eoradiolites) but this structure is also present in some advanced Requieniidae ("Toucasia-Apricardia "group). Canaliculate shell structures are convergent evolutionary traits which are common in the Caprinidae and Caprinuloideidae and also exist in the Polyconitidae and "Caprinulidae". In most of the foregoing canaliculated groups, two trends are well expressed, reflecting parallel evolution: expansion of canals into the entire shell and increasing complexity of canal architecture. Convergent taxa took some advantages by using former innovations. An Albian peak of convergence coincided with the emergence of new clades, which suggests a reset following the mid-Aptian extinction event.

Keywords: Monopleuridae; Eoradiolites; Caprinulidae; Hippuritidine Clade; Myophoral; Polyconitidae; Caprinidae

\section{Introduction}

Evolutionary convergence is implicated when two or more lineages with distinct ancestors independently evolve a similar morphological trait, a concept close to evolutionary parallelism which postulates that similarity may appear in lineages having a common origin and/or changed together in roughly similar fashion [1,2]. In bivalves, evolutionary convergence was established for post-Paleozoic Crassatellidae and Astartidae [3]. It was also documented for the acquisition of an opisthogyrate rostrate shell habit observed in infaunal taxa belonging to unrelated lineages, as an adaptation to shallow burrowing and allowing the animal to reach the water-sediment interface while the main body remained below the sediment surface [4,5]. In rudist bivalves canaliculated shell structures have also been regarded as convergent traits $[6,7]$.

The objectives of the present paper are to compile examples of convergent versus parallel evolution in Lower Cretaceous rudist bivalves (order Hippuritida) belonging to distinctive suborders or families from the Mediterranean, Caribbean and Asiatic paleobiogeographic entities. We first address two clades, the requieniide clade and the hippuritidine clade [8,9] (Figure 1) in which the arrangement of myophores and the shell structure show some similar patterns. We will also reappraise the similarity in distribution of canaliculated shell structures in distinctive families of the hippuritidine clade, and subclades, including their evolution through time. We discuss the relevance of the 


\section{International Journal of Paleobiology \& Paleontology}

concept of convergence and/or parallelism applied to the foregoing pattern of characters and analysed their relative timing. In the following we use the family names and authors proposed by Skelton $[8,9]$.

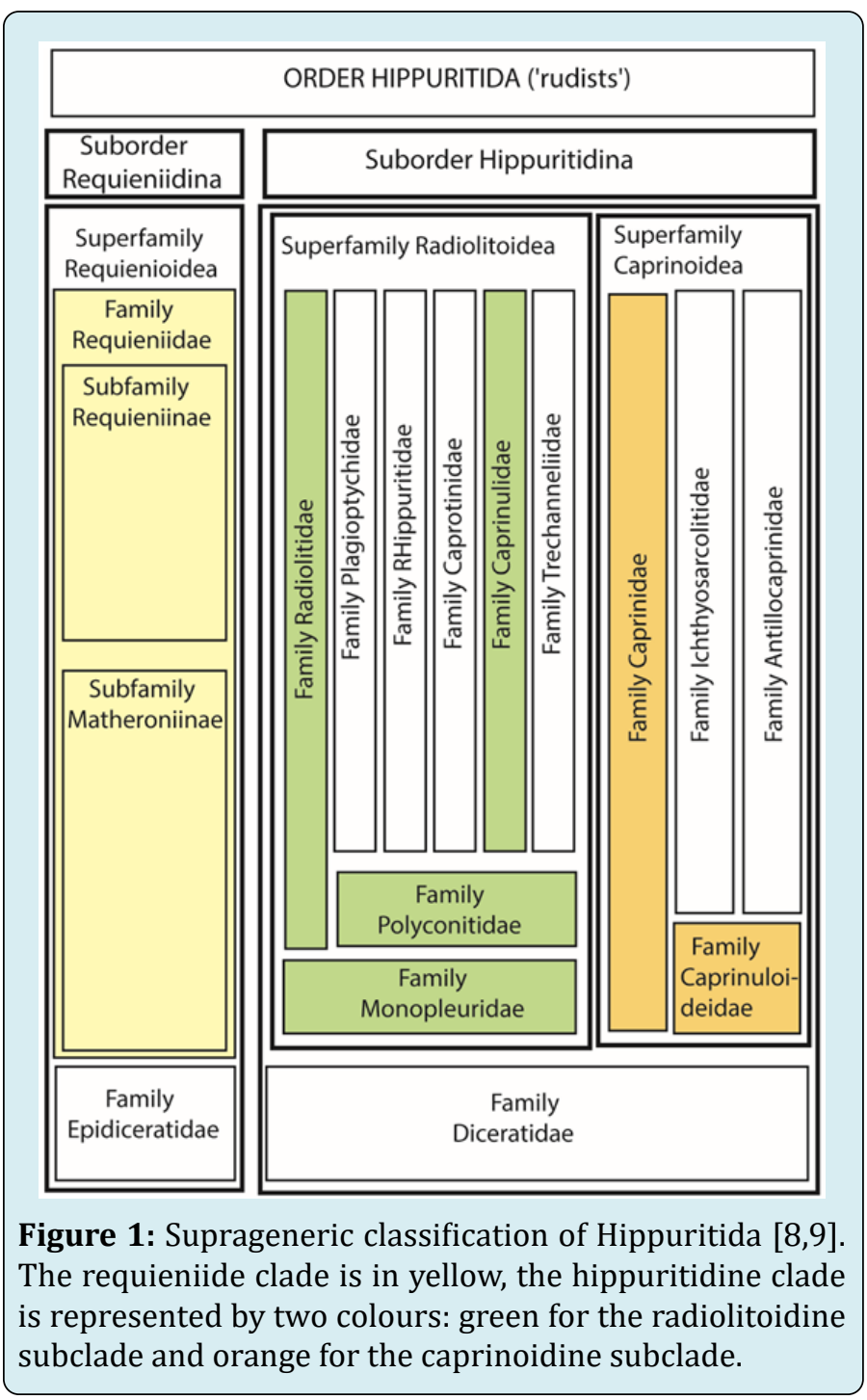

Abbreviations and codes used for the paleontological descriptions: BC, body cavity; A, anterior side; P, posterior side; $\mathrm{m}$, anterior and posterior muscles; am, anterior myophore; pmp, posterior myophoral plate; pmc, posterior myophoral cavity pt, posterior tooth; at, anterior tooth; as, anterior socket; ps, posterior socket. Muscles are figured in pale blue.

\section{Myophoral Arrangement in Rudist Bivalves}

Myophores are fundamental in rudist systematics and their diversity and phylogenetic conservatism are remarkable and possess a high taxonomic value $[6,7]$. Similar myophoral organisations recorded in distinctive clades may suggest phylogenetic affinities or may afford the opportunity to evaluate other patterns.

\section{The Requieniide Clade}

In the requieniide clade the shell is attached by the left valve (LV). Myophoral evolutionary patterns are well illustrated in the family Requieniidae Kutassy, which includes five genera having contrasting myophoral arrangements $[10,11]$. In Matheronia right valve (RV) myophores are located on low, salient bulges, whereas the LV myophores are on shell wall. In Requienia the RV is flattened and bears a posterior myophoral plate, the anterior is a low bulge; LV myophores being inconspicuous. Toucasia is characterized by posterior myophoral plates on both valves and the posterior side of the RV is raised above the commissure. The myophores of Lovetchenia are represented by shell transverse thickenings on both valves, and the RV is salient (Figure 2A) As Toucasia, Pseudotoucasia has posterior myophoral plates on both valves but the myophore of the RV is bent with an elbow shape (Figure 3A).

\section{The Hippuritidine Clade}

In the hippuritidine clade the shell is attached by the RV. Myophoral evolutionary patterns are well illustrated in two families, Monopleuridae Munier -Chalmas and Polyconitidae MacGillavry. As stated by Masse and FenerciMasse [12], the family Monopleuridae includes two groups of genera. To the first group belong Monopleura Matheron emend. and Homopleura Masse and Fenerci-Masse [12] with RV myophores located on flat transverse shell thickenings present either only on the posterior side, as in Monopleura or on both the anterior and posterior sides, as in Homopleura (Figure 2B). In the family Polyconitidae the $\mathrm{LV}$ posterior myophore is a bent lamina which consists of a plate subparallel to the commissure, attached basically to the shell by a pedicle, (Figure 3B), the anterior myophore is a vertical plate, in Horiopleura the RV posterior myophore is on a transverse shell thickening, the anterior on shell wall [13]. In Polyconites the myophoral organisation of the LV is nearly the same, the RV myophores being on shell wall. Pediculate myophores also exist in some Caprinuloideidae Damestoy, this is the case for the LV posterior myophore of Amphistricoelus warringi Harris and Hodson, represented by a vertical, slightly convex, plate supported by a pedicle attached to the posterior tooth [14] (Figure 3C).

\section{Convergent Patterns in Myophoral Arrangement}

The foregoing shows convergent patterns between the two clades, requieniide (family Requieniidae) and hippuritidine (families Monopleuridae, Polyconitidae and Caprinuloideidea), whereas the convergent traits are 


\section{International Journal of Paleobiology \& Paleontology}

recorded on the RV of the first group, they are located in the $\mathrm{LV}$ of the second group.

In Monopleura (Monopleuridae), Matheronia and Requienia (Requieniidae), the myophoral arrangement of the attached valve is similar. This similarity is recorded in primitive taxa of the two families. The transverse shell thickening of the myophores of the attached valve are convergent traits in Lovetchenia, i.e. L. lovetchensis (Zklatarski) (Requieniidae) (Figure 2A) and Homopleura, i.e. H.balkanica Masse and Fenerci-Masse (Monopleuridae) (Figure 2B); this morphology characterises relatively advanced taxa. In that case morphological identity corresponds with functional similarity. Inflated transverse myophores appear first in the requieniide clade in the Hauterivian then in the hippuritidine clade in the Barremian, it may reflect the resurgence of a primitive trend (atavism) recorded in diceratids [15].

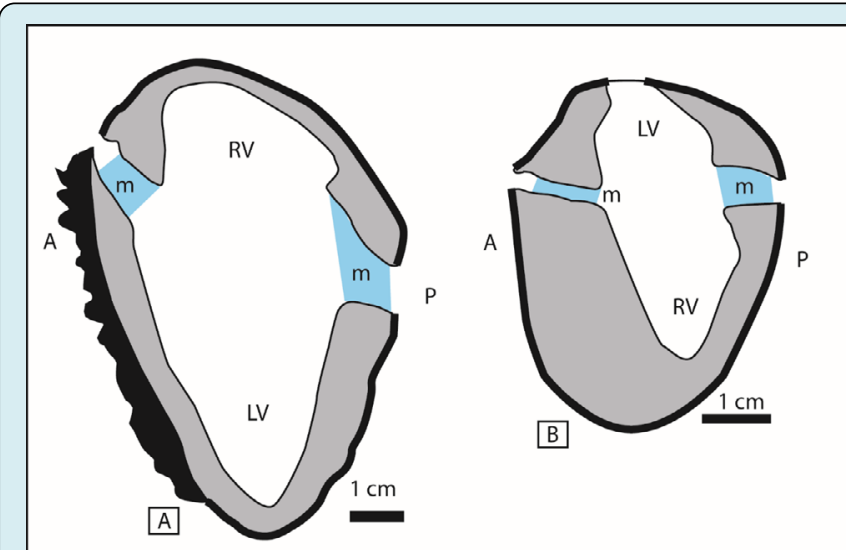

Figure 2: Convergent myophoral arrangement: transverse shell thickening, figures based on longitudinal sections of bivalve specimens. A, Lovetchenia lovetchensis (Zlatarski), from Lovetch, Bulgaria (Requieniidae) [15]. B, Homopleura balkanica Masse and Fenerci-Masse, from Emen, Bulgaria (Monopleuridae) [12]. Inner aragonitic shell layer is in grey, the calcitic outer shell layer in black.

The bent posterior myophore of the RV of Pseudotoucasia (Requieniidae) closely resembles the posterior myophore of the LV of Horiopleura and Polyconites (Polyconitidae). In Pseudotoucasia santanderensis (Douvillé) the myophore is elbow shaped (Figure 3A) and its tip points posteriorily, which mimics that of Horiopleura (Figure 3B). A similar myophoral organisation was described by Ayoub-Hannaa and Fürsich [16] in the Cenomanian requieniid "Apricardia" noncarinata from Egypt. The morphological similarity does not imply a functional identity in Pseudotoucasia for instance the muscle is inserted at the inflated apex of the myophore whereas in the Polyconitidae the muscle insertion is on the plate itself which parallels the commissural plan. This myophoral geometry typifies an advanced taxon of the Requieniidae and primitive forms of the Polyconitidae, it has a generic significance in Pseudotoucasia whereas in the Polyconitidae it is a marker of the family. The posterior myophore of the LV of Amphistricoelus (Caprinuloideidae) is also pediculate (Figure $3 \mathrm{C}$ ), the pedicle supports a vertical plate facing the posterior shell side [14].

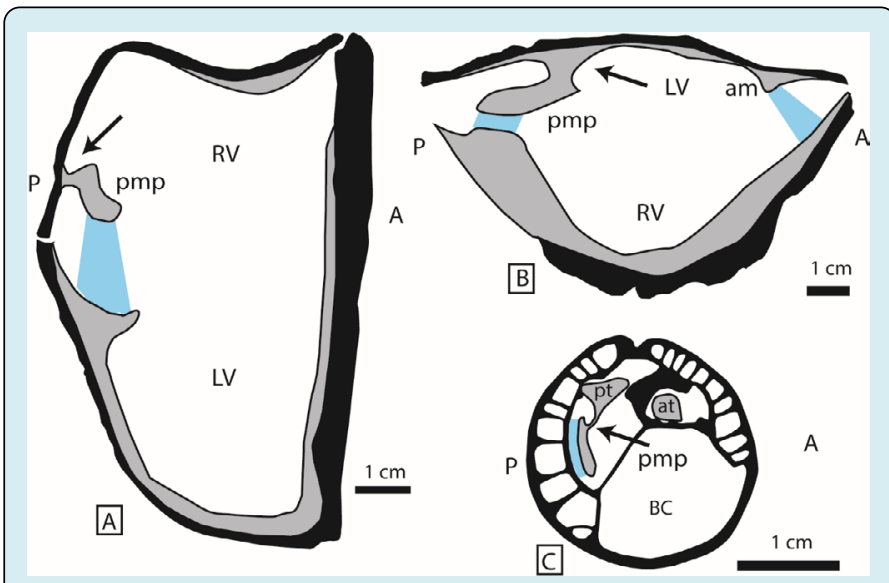

Figure 3: Convergent myophoral arrangement: bent (elbow shape) or pediculate myophores. A, B, longitudinal sections of bivalve specimens. A, Pseudotoucasia santanderensis (Douvillé), from Santander (Spain) [17]. B, Horiopleura gemmellaroi (di Stefano), from Northern Tunisia [13]. $\mathrm{C}$, transverse section of a RV of Amphitriscoelus warringi Harris and Hodson, fromTrinidad [14]. Arrow indicates the pediculate portion of the myophore. For Figure A and $\mathrm{B}$, the shell layers are represented as in Figure 2 .

\section{Shell Structures}

The basic shell structure of rudist bivalves is two layers, i.e. an inner shell layer, originally made of aragonite, from which myocardinal features are built, and an outer shell layer made of prismatic calcite [18]. In most taxa, but one, belonging to the requieniide clade, the double layer has a compact microstructure. In the Lower Cretaceous the hippuritine clade is also dominated by taxa having a compact double layering, but two additional arrangements have their FO during this time interval: cellular structures present in the calcitic outer shell layer, and canaliculated structures restricted to the inner formerly aragonitic shell layer. During the early Cretaceous the two basic structures didn't coexist whereas they were coeval in some late Cretaceous forms, e.g. the Campanian Pseudosabinia klinghardti (Boehm) [19,20].

\section{Cellular Versus Compact Structures}

The so-called cellular structure has been attributed to the association of funnel plates and radial plates [21], forming a network which is one of the key attributes of the family Radiolitidae d'Orbigny [22]. Early Cretaceous 


\section{International Journal of Paleobiology \& Paleontology}

representatives of the family are represented by Eoradiolites with a quadrangular outer shell layer structure and Archaeoradiolites with radially arranged branching walls.

It is worth noting that the primitive, Barremian member of the family, i.e. Agriopleura, has a compact outer shell $[23,24]$. A similar acellular structure, is recorded in the late Aptian-Albian radiolitid genus Auroradiolites, assumed to be a marker of the Asian-Pacific province [25,26]. The acellular Auroradiolites was considered as a direct descendant of Agriopleura [26], in that case the compact shell structure might be just inherited. Given the distinctive paleogeography (Asiatic versus Mediterranean) and the time gap (Barremian-early Aptian versus late Aptian-Albian) between the two genera, an alternative interpretation is proposed. Auroradiolites might derive through convergence from a former cellular form, e.g. Eoradiolites. Actually the development of cellular structures in advanced radiolitids shows that this pattern follows a juvenile compact stage through ontogeny [27], heterochrony is thus a more likely interpretation of the compact structure of Auroradiolites. Another case of convergence is illustrated by the genus Gorjanovicia which documents the re-inception of acellular Radiolitidae in the late Cretaceous [28].

Cellular structures tend to characterize the hippuritidine clade, nevertheless they have been also recorded in "Toucasia like" requieniids (unpublished data from the authors). Quadrangular cellular structures are present on the ventral side of the LV of specimens of Albian age from Laguna Colorada-El Madrono (Queretaro, Mexico) [29] and southern Italy. Similar structures were described by Palmer [30] in the requienid "Apricardia" asymmetrica Palmer from Paso del Rio, Colima (Mexico) in beds of Albian age (formerly assigned to the Cenomanian).

\section{Canaliculate Structures}

Canals tend to develop between vertical blades, when aligned along the outer shell margin one refers to pallial canals. They originate from the partitioning of cavities or gutters and have a significant record in several families with Lower Cretaceous representatives, e.g. Caprinidae d'Orbigny and Caprinuloideidae. Canals have their FO in Pachytraga tubiconcha Astre (Caprinidae) of Hauterivian age $[31,32]$. They play a major role in Caprinidae, e.g. Praecaprina varians Paquier (Figure 4A), Offneria (Figure 4B) and the Caprinuloideidae, e.g. Amphistroelus warringi (see Figure 3C). Pallial canals are present in the unrelated clade of "Caprinulidae" Yanin, 1990 (a family not recognized by Rineau, 2017, but independent from the Caprinidae), including Sellaea and Neocaprina [33,34]. Assuming a phylogenetic relationship between Himeraelites and Sellaea it is worth noting that canals, absent in Himeraelites, settled in Sellaea on the RV anterior shell margin, but not in the LV perimyophoral cavity, usually canaliculated in the Caprinidae. The existence of anterior and posterior canals is recorded in Neocaprina raghawiensis, (Figure 4C) a putative descendant of Sellaea [35]. Canals are not uncommon in Polyconitidae. The RV of Polyconites operculatus (Roulland) (pro Radiolites polyconilites d'Orbigny, 1842) has dorsal,vertical canals (see d'Orbigny, 1842, pl. 574, Figure 3 ).The LV posterior perimyophoral cavity of Magallanesia canaliculata Sano, et al. [36] (Figure 4D) and M. rutogensis Rao, et al. [25], bear a row of radial canals. In the LV posterior perimyophoral cavity of Praecaprotina yegashii (Yehara) canals are present in some specimens [37]. The foregoing data are a perfect illustration that canals evolved independently in several different clades $[18,7]$. So they are typical convergent evolutionary traits.

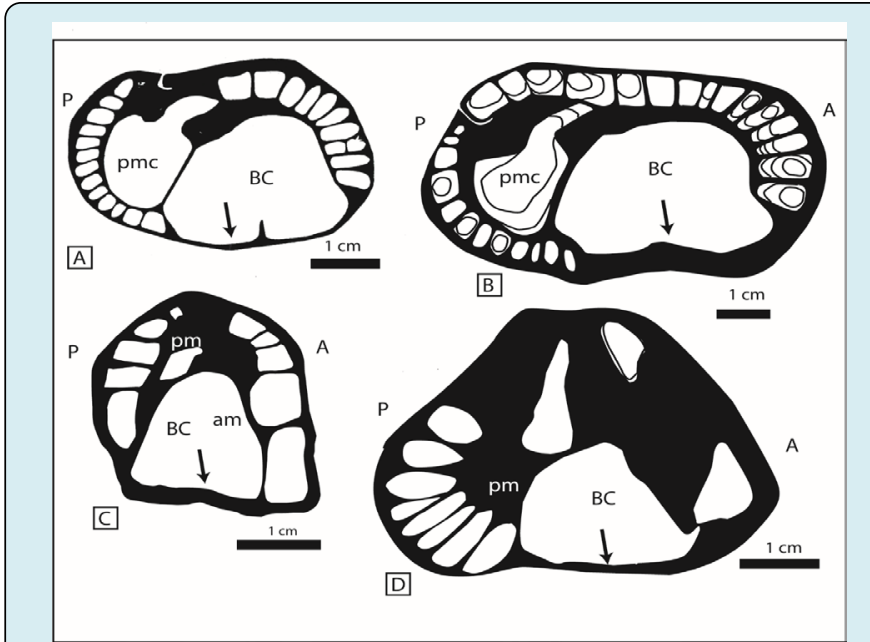

Figure 4: Pallial canals in Caprinidae, "Caprinulidae" and Polyconitidae, based on transverse sections. A, B Caprinidae. A, LV of Praecaprina varians Paquier, from SE France [14]. B, LV of Offneria simplex Chartrousse and Masse, from SE France [38]. C "Caprinulidae". LV of Neocaprina raghawiensis Steuber and Bachmann, from Sinai Peninsula [35]. D, Polyconitidae. LV of Magallanesia canaliculata Sano et al., from Cebu island, Philippines [36]. Arrow indicates the canal-free ventral side.

\section{Evolutionary Parallelism}

In the families Caprinidae, Caprinuloideidae and "Caprinulidae" the geometry, mode of development and expansion of canals in the shell are nearly identical and evolved similarly. As shown by Coogan [39] and Coogan in Dechaseaux, et al. and Mitchell $[40,41]$, canals of primitive forms are characterized by few simple radial walls, as in Praecaprina (Caprinidae) (Figure 4A) , Amphitriscoelus (Caprinuloideidae)(Figure 3C) and Neocaprina (Caprinulidae) (Figure 4C ). In these families the ventral side of primitive forms lack pallial canals, this is the case for Praecaprina (Figure 3A), Amphistriscoelus (Figure 3C), 


\section{International Journal of Paleobiology \& Paleontology}

Neocaprina raghawiensis Steuber and Bachman [35] (Figure 4C) and the primitive Offneria simplex Chartrousse and Masse (Figure 3B). By contrast, in more advanced forms, the number of canals increases and in some cases invade the ventral side, as in advanced species of Offneria (Figures 5B, 5C) [14,42], and Coalcomana (Figure 5D) [14]. This trend is not only recorded in caprinids but also in the Polyconitidae. This is the case of species of Magallanesia: the derived M.rutogensis Rao, et al. [25] has more canals than its putative ancestor M. canaliculata Sano et al. In the "Caprinulidae" too, the advanced Cenomanian species Neocaprina gigantea Plenicar [43-45] is more canaliculated than its Albian ancestor $N$. raghawiensis (Figure 4C and 5A). Quantitative changes in canal number are associated with modifications of their geometry: they bifurcate and tend to be subdivided, this is the case in the Caprinidae for species of Offneria (Figures 5B, 5C) [38], and in the Caprinuloideidae with Coalcomana ramosa (Boehm) (Figure 5D) and Caprinuloidea [14]. The geometrical changes are associated with an increasing structural complexity and the existence of several canal rows with distinctive geometries, a trend well illustrated in species of Offneria with 0 . simplex, a Barremian species, followed by 0 . rhodanica of late Barremian-early Aptian age and $O$. prebetica of the latest early Aptian (Figure 4B, 5B, 5C) $[24,38]$.

Convergence appears somewhat unlikely to account for: 1 - the expansion of canals into the entire shell, i.e. the invasion of the ventral margin, 2- the increasing complexity of canal architecture through time, two phenomena reflecting parallel evolution of distinct lineages rather than convergence.

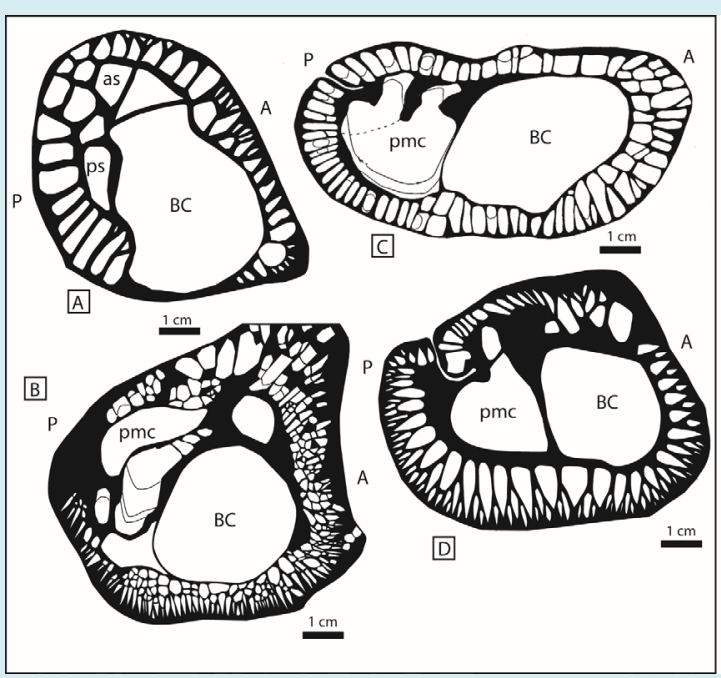

Figure 5: Canaliculate architectures in advanced forms of "Caprinulidae", Caprinidae and Caprinuloideidae, based on transverse sections. A, RV of Neocaprina gigantea Plenicar, fromTurkey [46]. B, LV of Offneria prebetica Masse et al., from Southern Spain [24]. C, LV of Offneria rhodanica Paquier, from SE France [14]. D, LV of Coalcomana ramosa (Boehm), from Mexico [14].

\section{Timing of Evolutionary Convergent Traits (Figure 6)}

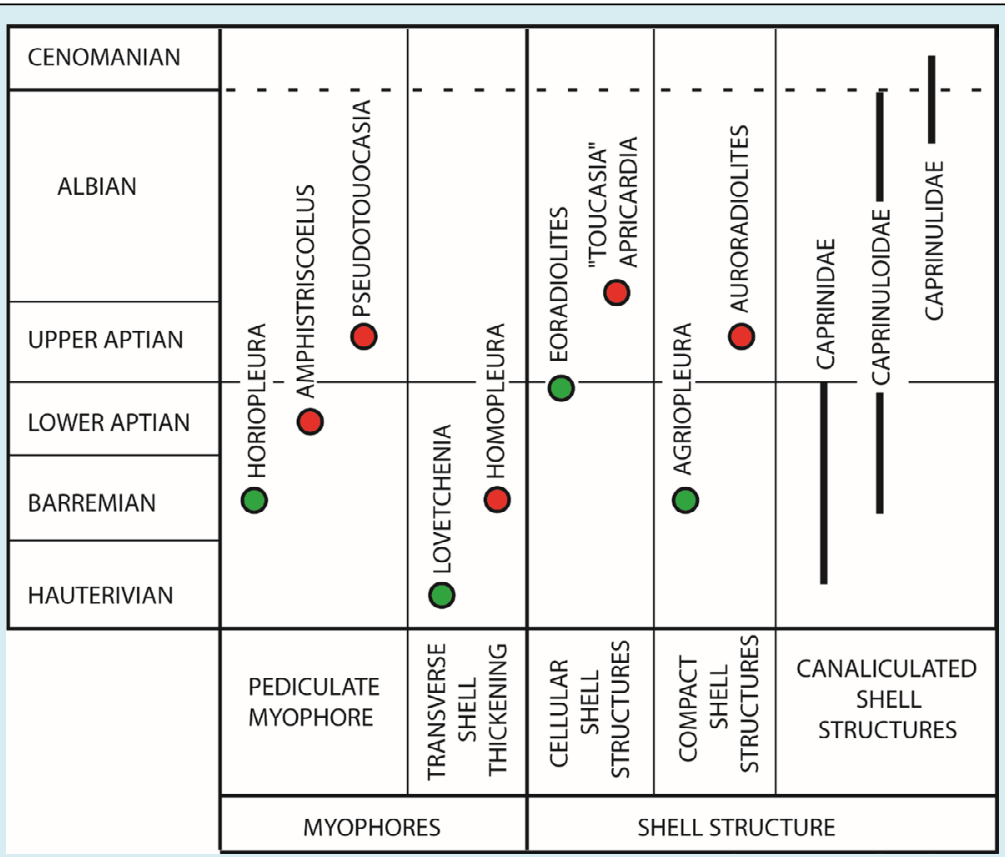

Figure 6: Timing of evolutionary convergent and parallel traits in early Cretaceous rudists. Red points mark the convergent taxa, green points their ancestors. 


\section{International Journal of Paleobiology \& Paleontology}

Pediculate posterior myophores are recorded in the Mediterranean hippuritide clade, in the Barremian -early Aptian genus Horiopleura, their Caribbean counterparts are nearly contemporaneous, e.g. the early Aptian Amphitriscoelus warringi. The convergent requieniide Pseudotoucasia, is younger, late Aptian- Albian. Cellular structures have their FO in the late Aptian radiolitid genera Archaeoradiolites and Eoradiolites, but the convergent requieniide representative "Toucasia-Apricardia group", is younger, Albian. Acellular species of Radiolitidae, i.e. Auroradiolites, are late Aptian-Albian. Canal system developed in late Hauterivian- Barremian and early Aptian, in Caprinidae and Caprinuloideidae, and evolved parallel patterns. By contrast canaliculate Polyconitidae and "Caprinulidae" started to expand in the Albian and Cenomanian.

The foregoing shows that a peak in convergent traits is in the late Aptian- Albian, mostly in the context of the "Albian radiation" of Rineau [7]. This radiation is marked by emergence of new clades and, in the Caribbean, by a diversity peak in the caprinuloids [47] with a strong turnover of the Youngicaprininae [41]. The late Aptian-Albian events suggest a reset following the mid-Aptian extinction event $[33,48]$.

\section{Discussion}

The strategy of pediculation implies that by contrast with a myophore on shell wall, muscles were not supported by a double (calcite+aragonite) shell layer, but a single nacremade layer. Actually nacre consists of aragonitic nannobricks and a complex organic phase, having a high tensile strength, high elasticity and high resistance to breaking [49,50]. Given the orthogonal geometry of the pedicle -myophore device we tentatively assign to elasticity a major functional role. As discussed earlier [22] the development of a cellular shell structure had several advantages: minimizing the cost of metabolic energy used for skeletal production, acquisition of thick shells, facilitating quick growth and increasing resistance to shell breakage and sponge boring. The restatement of compact shell structures has a clear paleobiogeographic component and so most probably a link with environmental conditions prevailing in the Asian-Pacific faunal province [33]. Convergent traits were essentially taken by taxa from Caribbean, Asiatic and Apulian regions, the rarity of European representatives is probably the result of a contemporaneous lowering in diversity due to an Albian environmental deterioration [51-58]. Convergent taxa took some advantages by using former innovations assumed to be driven by both biological processes or by environmental constraints.

\section{Conclusion}

Two clades of the Lower Cretaceous Hippuritida, requieniide (family Requieniidae) and hippuritide (families Radiolitidae, Polyconitidae, Caprinidae, "Caprinulidae" and Caprinuloideidae), possess distinctive myophoral arrangements and shell structures. But they share some similar characters located in the $\mathrm{RV}$ of the first group and in the LV of the second group. The transverse shell thickening of the myophores of the attached valve are convergent traits in Lovetchenia (Requieniidae) and Homopleura (Monopleuridae). The bent posterior myophore of the RV of Pseudotoucasia (Requieniidae) closely resembles the posterior myophore of the LV of Horiopleura and Polyconites (Polyconitidae). The shell cellular structure is one of the key attributes of the family Radiolitidae (e.g. Eoradiolites) but this structure is also present in some advanced Requieniidae ("Toucasia-Apricardia" group). The restatement of acellular Radiolitidae is a late Aptian -Albian event connected with the Asian -Pacific faunal province. Canaliculate shell structures which are common in the Caprinidae and Caprinuloideidae are also present in Polyconitidae and "Caprinulidae", and have long been considered as convergent evolutionary traits. In the foregoing canaliculated groups, with the exception of the Polyconitidae two trends are well expressed, 1- the expansion of canals into the entire shell, i.e. the invasion into the ventral margin, 2- the increasing complexity of canal architecture through time, these two phenomena reflect parallel evolution. Convergent taxa took some advantages by using former innovations. The late Aptian-Albian peak of convergence coincides with the emergence of new clades, mostly in the Caribbean and South Tethyan Mediterranean margins, it suggests a reset following the mid-Aptian extinction event.

\section{References}

1. Sheldon P, Skelton PW (1993) Phylogenetic patterns. The Open University 54423L: 743-852.

2. Pearce $T$ (2012) Convergence and parallelism in evolution: a neo-Gouldian account. British Society for the Philosophy of Science 63(2): 429-448.

3. Boyd DW, Newell ND (1968) Hinge grades in the evolution of Crassatellacean bivalves as revealed by Permian genera. American Museum Novitates 2328: $1-52$.

4. Stanley SM (1977) Coadaptation in the Trigoniidae, a remarkable family of burrowing bivalves. Palaeontology 20(4): 869-899.

5. Echevarria J, Damboreana SE, Mancenido MO (2017) Constructional morphology of the shell/ligament system in opisthogyrate rostrate bivalves. Earth and Environmental Science Transactions of the Royal Society of Edinburgh 106(4): 221-227. 


\section{International Journal of Paleobiology \& Paleontology}

6. Skelton PW (1978) The evolution of functional design in rudists (Hippuritacea) and its taxonomic implications. Philosophic Transactions of the Royal Society B 284(1001): 305-318.

7. Rineau V (2017) Un nouveau regard cladistique sur l'anatomie comparee, la phylogenie, la systematique et la paleoecologie des rudistes (Bivalvia, Hippuritida). UPMC, pp: 623.

8. Skelton PW (2013a) Rudist classification for the revised Bivalvia volumes of the "Treatise on Invertebrate Palaeontology". Caribbean Journal of Earth Sciences 45: 9-33.

9. Skelton PW (2013b) Rudist classification: nomenclatural correction of "Suborder Radiolitidina Skelton, 2013" to "Suborder Hippuritidina Newell, 1965". Caribbean Journal of Earth Sciences 45: 34.

10. Douville H (1915) Les réquiénidés et leur évolution. Bulletin de la Société Géologique de France 4(14): 383389.

11. Masse JP (1994) L'évolution des Requieniidae (Rudistes) du Crétacé inférieur : caractères, signification fonctionnelle, adaptative et relations avec les modifications des paléoenvironnements. Géobios 27(3): 321-333.

12. Masse JP, Fenerci Masse M (2019) Homopleura new genus (Hippuritida, Monopleuridae), and the origin of the Polyconitidae. Cretaceous Research 97: 107-124.

13. Masse JP, Fenerci Masse M (2017) Taxonomy and stratigraphy of late Barremian-Albian species of Horiopleura Douvillé (Hippuritida, Polyconitidae). Cretaceous Research 76: 53-80.

14. Chartrousse A (1998) Les Caprinidae (Rudistes) du Crétacé inférieur. Thèse Université de Provence, pp: 281.

15. Masse JP (1993) Systématique, stratigraphie et paléobiogéographie du genre Lovetchenia (Requieniidae) du Crétacé inférieur méditerranéen. Géobios 26(6): 699708.

16. Ayoub Hannaa W, Fursich FT (2012) Apricardia noncarinata n.sp. (Bivalvia, Requieniidae) from the Cenomanian (Upper Cretaceous) of central-east Sinai, Egypt. Neues Jahrbuch für Geologie und Paläontologie 263(1): 75-84.

17. Masse JP (1996) Lower Cretaceous rudist biostratigraphy of southern France: a reference for Mesogean correlations. Revista Mexicana de Ciencias Geologicas 12(2): 236-256.
18. Skelton PW (2018) Treatise Online no. 104: Part N, Volume 1, Chapter 26A: Introduction to the Hippuritida (rudists): Shell structure, anatomy, and evolution. Treatise Online, pp: 101-114.

19. Morris NJ, Skelton PW (1995) Late CampanianMaastrichtian rudists from the United Arab EmiratesOman border region. Bulletin of the British Museum (Natural History), Geology Series 51: 277-305.

20. Özer S (2010) Campanian-Maastrichtian Pseudosabinia from Turkey: descriptions and taxonomic problems. Turkish Journal of Earth Sciences 19: 643-669.

21. Milovanovic B (1935) Contribution à la connaissance de la couche externe des rudistes. Bulletin du Service géologique du Royaume de Yougoslavie 4(1): 85-125.

22. Fenerci Masse M, Masse JP, Arias C, Vilas L (2006) Archaeoradiolites, a new genus from the Upper Aptian of the Mediterranean region and the origin of the rudist family Radiolitidae. Palaeontology 49(4): 769-794.

23. Masse JP, Philip J (1974) Définition, position systématique, répartition stratigraphique et évolution du genre Agriopleura Kühn (Rudistes). Géologie Méditerranéenne 1(2): 53-62.

24. Masse JP, Fenerci Masse M, Arias C, Vilas L (2015) Description of a new species of Offneria (Hippuritida, Caprinidae) from the Lower Aptian of southeast Spain. Stratigraphic, evolutionary, palaeobiogeographic and palaeoenvironmental implications. Cretaceous Research 53: 153-166.

25. Rao X, Skelton PW, Sha J, Cai H, Iba Y (2015) MidCretaceous rudists (Bivalvia: Hippuritida) from the Langshan Formation, Lhasa Block, Tibet. Palaeontology 1(4): 401-424.

26. Rao X, Skelton PW, Sano SI, Pan Y, Luo H, et al. (2017) Evolution and palaeogeographical dispersion of the radiolitid rudist genus Auroradiolites (Bivalvia, Hippuritida) with description of new material from Tibet and archived specimens from Afghanistan. Palaeontology 3(2): 297-315.

27. Masse JP, Philip J (1972) Observations sur la croissance et l'ontogenèse du test des radiolitidae (Rudistes). Conséquences phylogénétiques et paléoécologiques. Comptes Rendus de l'Académie des Sciences, Paris 274: 3202-3205.

28. Fenerci Masse M, Skelton PW, Masse JP (2011) The rudist bivalve Gorjanovicia (Radiolitidae, Hippuritoidea) a revision based on quantitative analysis of morphological 


\section{International Journal of Paleobiology \& Paleontology}

characters. Palaeontology 54(1): 1-23.

29. Alencaster G, Garcia Barrera P (2008) Albian radiolitid rudists (Mollusca, Bivalvia) from East-Central Mexico. Géobios 41(5): 571-587.

30. Palmer RH (1928) The rudists of southern Mexico. Occasional papers of the California Academy of Sciences 14: 1-137.

31. Astre G (1961) Pachytraga tubuleux du Barrémien du Doubs. Bulletin de la Société d'Histoire Naturelle de Toulouse 96(3-4): 205-222.

32. Skelton PW, Masse JP (1998) Revision of the Lower Cretaceous rudist genera Pachytraga Paquier and Retha Cox (Bivalvia, Hippuritacea) and the origins of the Caprinidae. Géobios, Mémoire spécial 21(1): 331-370.

33. Skelton PW, Sano SI, Masse JP (2013) Rudist bivalves and the Pacific in the Late Jurassic and Early Cretaceous. Journal of the Geological Society, London 171(4): 513526.

34. Rineau V, Masse JP, Villier L (2020) A new cladistic insight on comparative anatomy and phylogeny of rudists (Bivalvia, Hippuritida). Journal of Systematic Palaeontology 18(15): 1243-1297.

35. Steuber T, Bachmann M (2002) Upper Aptian- Albian rudist bivalves from northern Sinai, Egypt. Palaeontology 45(4): 725-749.

36. Sano SI, Iba Y, Skelton PW, Masse JP, Aguilar YM, et al. (2014) The evolution of canaliculated rudists in the light of a new canaliculated polyconitid rudist from the Albian of the Central Pacific. Paleontology 57(5): 951-962.

37. Yehara S (1920) A pachyodont lamellibranch from the Cretaceous deposits of Miyako in Rikuchu. Journal of the geological society of Tokyo 27(321): 39-44.

38. Chartrousse A, Masse JP (1998) Offneria simplex nov. sp. (rudiste, Caprinidae) du Barrémien du sud-est de la France et de Cuba. Implications sur la biostratigraphie et l'évolution du genre Offneria. Bulletin de la Société géologique de France 169(6): 841-850.

39. Coogan AH (1973) New rudists from the Albian and Cenomanian of Mexico and South Texas. Revista del Instituto Mexicano del Petroleo 5(2): 51-83.

40. Dechaseaux C, Coogan AH, Perkins BF, Cox LR (1969) Superfamily Hippuritacea Gray, 1848. In: Moore RC (Eds.), Treatise on Invertebrate Paleontology, part $\mathrm{N}$ Mollusca 6, Bivalvia. Geological Society of America, pp: N749-N817.
41. Mitchell SF (2013) A revision of selected Lower Cretaceous American caprinoid rudists: implications for phylogeny and biostratigraphy. Caribbean Journal of Earth Sciences 45: 47-75.

42. Masse JP (1992) Les rudistes de l'Aptien inférieur d'Italie continentale : aspects systématiques, stratigraphiques et paléobiogéographiques. Geologica Romana 28: 243-260.

43. Plenicar M (1961) The stratigraphic development of Cretaceous beds in southern Primorska (Slovene littoral) and Notranjska (inner Carniola). Geologija 6: 22-145.

44. Plenicar M (1963) Caprinidae and the genus Radiolitella from the Upper Cretaceous strata of southwestern Slovenia. Slovenska Akademija Znanosti in Umetnosti, razred za prirodolovne in medicinske Vedei Razprave 7: 559-587.

45. Özer S, Kahriman HH (2019) Cenomanian canaliculated rudists (Bivalvia) from the Geyik Dagi-Hadim area (Central Taurides, S Turkey): systematic paleontology, stratigraphic importance and depositional environment. Cretaceous Research 103: 104161.

46. Özer S (1988) Description de quelques rudistes à canaux dans le Cénomanien de Turquie. Géologie Méditerranéenne 15(2): 159-167.

47. Scott RW, Filkorn HF (2007) Barremian-Albian rudist zones, U.S. Gulf Coast. In: Cretaceous rudists and carbonate platforms: environmental feedback, SEPM Society for Sedimentary Geology 87: 167-180.

48. Masse JP (1989) Relations entre modifications biologiques et phénomènes géologiquessur les platesformes carbonatées du domaine périméditerranéen au passage Bédoulien-Gargasien. Géobios Mémoire spécial 22(1): 279-294.

49. Jackson AP, Vincent JFV, Turner RM (1988) The mechanical design of nacre. Proceedings of the Royal society.

50. Katti K, Katti DR, Tang J, Pradhan S, Sarikaya M (2005) Modeling mechanical responses in a laminated biocomposite. Journal of Materials Science 40: 17491755 .

51. Masse JP, PhilipJ(1986) L'évolution des rudistes au regard des principaux évènements géologiques du Crétacé. Bulletin du Centre de Recherches et d'ExplorationProduction, Elf-Aquitaine 10(2): 437-456.

52. Masse JP, Arias C, Vilas L (1998) Lower Cretaceous rudist faunas of southeast Spain: an overview. In: Masse JP, Skelton PW, (Eds.), Quatrième Congrès International sur 


\section{International Journal of Paleobiology \& Paleontology}

les Rudistes, Géobios, Mémoire Spécial 31(1): 193-210.

53. Masse JP, Gourrat C, Orbette D, Schmuck D (1998) Hauterivian Rudist faunas of southern Jura (France). In: Masse JP, Skelton PW, (Eds.), Quatrième Congrès International sur les Rudistes, Géobios, Mémoire Spécial 31(1): 225-233.

54. Damestoy G (1971) Essai de classification phylogénétique des Caprinidés (Lamellibranches). Bulletin du Museum National d'Histoire naturelle 2(42): 1003-1008.

55. Gili E, Masse JP, Skelton PW (1995) Rudists as gregarious sediment-dwellers, not reef-builders, on Cretaceous carbonate platforms. Palaeogeography
Palaeoclimatology Palaeoecology 118(3-4): 245-267.

56. Masse JP, Fenerci Masse M (2020) Taxonomy and biostratigraphy of Early Cretaceous species of the genus Monopleura Matheron (Hippuritida, Monopleuridae) of the Mediterranean region. Cretaceous Research 108: 10428 .

57. Orbigny d'A (1851) Paléontologie Française; Terrains crétacés. IV, Atlas.

58. Skelton PW (2014) Why myophores are fundamental in rudist systematics. Tenth International Congress on rudist bivalves, Bellaterra, Scientific Program and Abstracts, pp: 21. 